\title{
Dairy meals of hospitalized children as a source of energy, calcium and phosphorus in satisfying their daily needs
}

\author{
Diana Vukman ${ }^{1 *}$, Tena Niseteo ${ }^{1}$, Petra Kučan ${ }^{1}$, \\ Nataša Mikulec ${ }^{2}$, Darko Grbeša ${ }^{3}$, Neven Antunac ${ }^{2}$ \\ ${ }^{1}$ Children's Hospital Zagreb, Klaićeva 16, 10000 Zagreb, Croatia \\ ${ }^{2}$ University of Zagreb, Faculty of Agriculture, Department for Dairy Science, \\ Svetošimunska 25, 10000 Zagreb, Croatia \\ ${ }^{3}$ University of Zagreb, Faculty of Agriculture, Department of Animal Nutrition, \\ Svetošimunska 25, 10000 Zagreb, Croatia \\ Received - Prispjelo: 16.02.2015. \\ Accepted - Prihvaćeno: 16.05.2016.
}

\begin{abstract}
A dairy meal is defined as a specific food serving composed from milk and dairy products. Because of its nutritional value and complex chemical composition, milk and dairy products play an important role in the diet of children and represent a rich source of calcium, phosphorus, as well as valuable proteins, B vitamins and minerals. Healthy children should consume at least three servings of dairy products daily, which contributes to the total energy and nutrients that children need. The needs of an unhealthy child are often higher than those who are healthy and depend on the state of the body. The aim of this study was to determine the incidence of consumption of dairy meals in hospitalized children and to find out if their energy needs, as well as their need for calcium and phosphorus through the consumption of the same were met. Significant differences were found between recommended energy intake from dairy products and actual energy intake from consumed milk and dairy products in three Croatian regions $(\mathrm{P}=0.021)$ tested. The highest values were recorded in central Croatia (253 Kcal or $34.4 \%$ ) and the lowest in the northern Croatian coastal region (17.05 Kcal or $20.1 \%$ ), which indicates a greater representation of milk and dairy meals in children's daily menu. Furthermore, hospitalized children meet almost half of their recommended daily intake of calcium and phosphorus from dairy meals for all three regions. The highest rate was found in central Croatia, $48.7 \%$ or $400 \mathrm{mg}$ of calcium, respectively $42.9 \%$ or $322.69 \mathrm{mg}$ phosphorus, while the remaining portion of calcium and phosphorus originates from different rich non-dairy food sources. In all regions the most common forms of dairy foods consumed were milk and dairy desserts.
\end{abstract}

Key words: dairy meal, energy value, calcium, phosphorus, milk and dairy products, hospitalized children

\section{Introduction}

A varied and balanced diet, as well as the adequate absorption of nutrients are basic prerequisites for maintaining health and balance of all energy and metabolic processes. Clinical nutrition includes all forms of patients' nutrition, primarily the normal oral intake, then the specially modified diet and nutritional supplements, as well as enteral and paren- teral nutrition. The usual oral nutrition of patients is based on basic nutritional postulates and represents the best way of nutritional support.

The goal of the hospital diet is to meet the energy and nutritional needs; in this case needs of paediatric patients according to their daily needs, considering guidelines for healthy children. In order to achieve the daily needs required for normal 
growth and development, considering the age of the child, the European Society for Paediatric Gastroenterology, Hepatology and Nutrition (ESPGHAN) and the Croatian national societies (Croatian Paediatric Society and the Croatian Society for Paediatric Gastroenterology, Hepatology and Nutrition) give strong recommendations for the intake of certain food groups, as well as milk and dairy products (Agostoni et al., 2005; Kolaček et al., 2009).

Regular consumption of dairy products is associated with a number of favourable health effects on human body and is an important factor of a balanced diet. For children and adolescents, foods from this group are of particular importance because they are rich in high-quality protein, vitamins and minerals necessary for proper growth and development (Antunac and Havranek, 2013). This important group of foods is an integral part of dietary guidelines of many nutritional institutions, and recommendations for a regular consumption of milk and dairy products is also issued by the World Health Organization. Several members of the European Union (France, Belgium, Ireland and Spain), recommend
3-4 servings of dairy products a day for children, while in Denmark, Finland and the Netherlands a daily intake of about $500-600 \mathrm{~mL}$ (2-3 servings) of dairy products is recommended. The nutritional guidelines of New Zealand for healthy children and young people (2-18 years), suggest that preschool children should consume at least 2-3 servings of milk and dairy products, like cheese and yogurt and for adolescents up to 18 years at least 3 servings per day (Ministry of Health, 2012).

Calcium originating from dairy products is highly available and represents more than $50 \%$ of the total calcium intake for children in European countries (Coudray, 2011). It is an essential macromineral, very important for the bone structure, as well as for the mineralization of bones and teeth. Furthermore, calcium is also important for normal blood clotting, energy metabolism, muscles and the nervous system, as well as for the normal work of the digestive tract (Miller et al., 2006). Milk and dairy products are rich dietary sources of calcium (Table 1). Moreover, the absorption of calcium is the highest from these foods. Although calcium can be obtained from

Table 1. The calcium (Ca) and phosphorus (P) content in dairy products (USDA, 2015)

\begin{tabular}{ccc}
\hline Dairy product & $\begin{array}{c}\text { Ca content } \\
\mathrm{mg} / 100 \mathrm{~g} \text { food }\end{array}$ & $\begin{array}{c}\text { P content } \\
\mathrm{mg} / 100 \mathrm{~g} \text { food }\end{array}$ \\
\hline Semi hard cheese & 700 & 546 \\
\hline Cream cheese & 225 & 248 \\
\hline Fruit yogurt & 152 & 119 \\
\hline Ice-cream & 128 & 105 \\
\hline Yogurt & 121 & 95 \\
\hline Milk, raw, 3,2 \% fat & 120 & 84 \\
\hline Cottage cheese & 111 & 150 \\
\hline Sour cream, $12 \%$ fat & 104 & 95 \\
\hline Pudding & 40 & 41 \\
\hline Butter & 24 & 24 \\
\hline
\end{tabular}

Table 2. Recommendations for daily energy intake and intake of calcium and phosphorus considering age of a child (DGE, 2000)

\begin{tabular}{ccccccccc}
\hline Age & $\begin{array}{c}0-4 \\
\text { (month) }\end{array}$ & $\begin{array}{c}4-12 \\
\text { (month) }\end{array}$ & $\begin{array}{c}1-4 \\
\text { (year) }\end{array}$ & $\begin{array}{c}4-7 \\
\text { (year) }\end{array}$ & $\begin{array}{c}7-10 \\
\text { (year) }\end{array}$ & $\begin{array}{c}10-13 \\
\text { (year) }\end{array}$ & $\begin{array}{c}13-15 \\
\text { (year) }\end{array}$ & $\begin{array}{c}15-19 \\
\text { (year) }\end{array}$ \\
\hline Kcal/day & 500 & 700 & 1200 & 1400 & 1700 & 1900 & 2300 & 2600 \\
\hline $\mathrm{Ca} /$ day (mg) & 220 & 330 & 600 & 750 & 900 & 1100 & 1200 & 1200 \\
\hline $\mathrm{P} /$ day (mg) & 120 & 300 & 500 & 600 & 800 & 1250 & 1250 & 1250 \\
\hline
\end{tabular}


other dietary sources, such as green leafy vegetables, legumes, seeds and some fruits, milk contains other nutrients, primarily phosphorus, vitamin D, magnesium, zinc and proteins which improve calcium absorption and support bone metabolism. In addition, milk belongs to food that contains the highest amount of calcium per serving unit (Alebić, 2008). A glass of partially skimmed milk of $200 \mathrm{~mL}$ provides about $55 \%$ of daily needs to a 6 -year-old child, while for adults (19-64 years) it can provide more than a third (35\%) of the required daily calcium intake (Department of Health, 1991; Food Standards Agency, 2002). The $\mathrm{Ca} / \mathrm{P}$ (1.4:1) ratio in milk is favourable, similar to the ratio in the human organism (bones). The utilization of calcium depends on its form and on the phosphorus and vitamin D concentration. Phosphorus is the second most abundant mineral in the human body after calcium, and about $85 \%$ is found as a part of chemical compound together with calcium (Tratnik and Božanić, 2012). Both phosphorus and calcium play an important role in maintaining healthy teeth and bones, as well as the structure of cell membranes and the regulation of metabolism energy (Miller et al., 2006). It is an integral part of the DNA and RNA, which makes it an essential element for all the growth processes, and many vitamins and enzymes become active only in contact with phosphorus (Antunac and Havranek, 2013).

Recommendations for the daily intake of energy, calcium and phosphorus differ significantly according to the age of a child, as shown in Table 2 (DGE, 2000).

Children's diet, eating attitudes and behaviour depends on the tradition and customs of the family and community. Different factors can affect the consumption of dairy products of a child. Parents influence children's consumption of milk and dairy products, and if they consume more milk, it is very likely that their children will also consume more milk and dairy products (Reicks et al., 2011). Although milk and dairy products are considered to be very important in the diet of children, their consumption is declining, and one of the main reasons is the increased consumption of sweetened soft drinks. The taste and sensory characteristics of food have a huge impact on children when choosing food, which is supported by the results of the study of De Pelsmaeker et al. (2013) suggesting that most children prefer flavoured milk with a certain taste instead of regular milk.

The aim of this study was to determine the incidence of consumption of dairy meals (milk, yogurt, cottage cheese, semi-hard and hard cheese, cream cheese, butter, ice cream and milk pudding) in hospitalized children and to find out if their energy needs, as well as their need for calcium and phosphorus through the consumption of the same were met. In addition, the authors wanted to determine the frequency of consumption and preferences of different dairy products in hospitalized children.

\section{Subjects and methods}

\section{Subjects}

The study was conducted within the one-day cross-sectional examination as part of the international Nutrition Day study, in order to assess the quality of hospital food. The subjects were hospitalized children $(n=140)$ in three tertiary care institutions in central Croatia, at the northern Croatian coast and in eastern Croatia. The subjects were enrolled into the study at ten paediatric departments (pulmonology, nephrology, toxicology, surgery, neurology, cardiology, gastroenterology, genetics, burns and oncology) and divided into three groups according to the type of disease:

a) Acutely ill children - departments: pulmonology (except for cystic fibrosis and nutritional allergies), nephrology, toxicology, surgery (except for burns and orthopaedics) and neurology. In these departments are mostly hospitalized children with acute illnesses, who remain hospitalized for relatively short time ( $<3$ days), for diagnostic purposes and to improve their general condition;

b) Chronically ill children - departments: cardiology, pulmonology, gastroenterology, genetics, burns and orthopaedics. In these departments are mostly hospitalized children with chronic illnesses and their hospital stay is longer ( $>3$ days),

c) Oncology patients - hospitalized children with various malignant diseases. Due to the specific features of the disease and mostly long-lasting treatments these children were observed separately in the study, although malignant diseases are considered a chronic form of disease. 
The criteria for inclusion into the study were as follows: children aged 0 months to 18 years, hospitalized at the time of the study and a signed informed consent by their parents or guardians. The exclusion criteria were: patients aged over 18 years, children in the day ward, those whose parents/guardian or the child refused to give consent to participation in the study, children in the intensive care ward and patients who were inaccessible due to prolonged examinations.

Different dietary questionnaires were used: standardized Nutrition Day questionnaires, 24-hour dietary recall, Food Frequency Questionnaire (FFQ) and a questionnaire about the frequency of milk and dairy products consumption (FFQ - milk). The questionnaires were filled by trained nutritionists. The parents/guardians who were in the hospital together with their children and who participated in their treatment were also involved in the completion of the questionnaire.

\section{Methods}

All data of the general condition and diagnosis of the patients were taken from the hospital records and used to classify the patients into three groups: acutely ill, chronically ill and oncology patients. To get information about patient energy and nutrient intake standardized dietary methods were carried out: 24-hour recall, one-day food diary and a questionnaire of the food frequency consumption (FFQ). All the above methods were performed on the day of testing. The data on food consumption in the past 24 hours were obtained with the 24-hour recall method. Subjects who were not hospitalized the previous day, reported what they had consumed in and outside the hospital. A trained person interviewed the subjects or their parents/guardians who recalled in detail all the food and drink consumed in the past 24 hours. During the 24 hours, a one-day food diary was carried out. As the study population was paediatric, to reduce the possibility of wrong information, the querist recorded everything the child consumed during the day of the survey, immediately after every meal. Food and drinks consumed, not as a part of hospital menu, were also recorded.

In order to obtain a better insight into the dietary habits and food intake of patients, a quantitative survey of food and beverages frequency consumption (FFQ) for the Croatian population was carried out. This questionnaire was developed and validated for the paediatric population based on traditionally consumed foods in Croatia (Močić Pavić et al., 2015).

Nutritional and energy average values for milk and dairy products, the calculation of the daily needs from milk and dairy products, as well as the value of serving units, according to which are prepared hospital meals for children are shown in tables 3, 4 and 5 .

\section{Data Processing}

The values obtained from the questionnaires were calculated using the integrated hospital information program - Dietitian (IN2 d.o.o., 2011), based on tables of foods and beverages composition (Kaić Rak et al., 1990). The programme was updated and filled with new foods according to the manufacturer's specifications and adjusted according to the German-Austrian-Swiss guidelines for an adequate nutrient intake (DGE, 2000). Quantitative data is presented through the median and interquartile range and through Box and Whisker's plots, while the nominal and categorical data is shown through the frequentness and absolute frequency. According to the analysis of normal data distribution within the Kolmogorov-Smirnov test, in further statistical analysis non-parametric Kruskal-Wallis tests were used for quantitative data and $\mathrm{X}^{2}$ tests for categorical data. Patients who did not consume milk and dairy products at all are excluded from the analysis. All values $\mathrm{P}<0.05$ were considered not statistically significant. The software IBMSPSS, Statistics version 21.0 (www.spss.com) was used for the analysis.

\section{Results and discussion}

\section{Study subjects}

From 217 hospitalized paediatric patients, 140 patients were included into the study due to exclusionary criteria; 61 or $28.11 \%$ of the study patients were acutely ill, 58 or $26.72 \%$ chronically ill and 21 or $9.67 \%$ of patients had malignant diseases (cancer patients). The differences between the sexes were not significant $(\mathrm{P}=0.096)$ - there were 75 girls $(53.6 \%)$ and 65 boys ( $46.4 \%)$. The mean age of the recruited patients was 8.5 years $\pm 5.9 \mathrm{SD}$ and most of hospitalized children $(\mathrm{N}=50$ or $35.8 \%)$ were school 
Table 3. Nutritional and energy average value of one unit serving for certain food groups

\begin{tabular}{ccccc}
\hline Food group & Protein $(\mathrm{g})$ & Fat (g) & Carbohydrates (g) & Energy (Kcal) \\
\hline $\begin{array}{c}\text { Bread and substitute (cereals, rice, pasta, } \\
\text { potato and other starchy foods) }\end{array}$ & & 2 & 15 & $70(118)$ \\
\hline Legumes & 5 & 0 & 15 & 83 \\
\hline Milk and substitute (dairy products) & 7 & $3(7)^{*}$ & 10 & $95(131)^{*}$ \\
\hline Meet and substitute & 7 & $2(7-12)^{*}$ & 0 & $46(93-140)^{*}$ \\
\hline Vegetables & 0 & 0 & 5 & 60 \\
\hline Fruit & 0 & 0 & 15 & 60 \\
\hline Fats and foods with high fat content & 0 & 5 & 0 & 45 \\
\hline Sugar and foods with high sugar content & 0 & $0(5)^{*}$ & 10 & $40(85)^{*}$ \\
\hline
\end{tabular}

${ }^{*}$ The figures in brackets refer to the food from certain groups of foods which contain a significantly higher proportion of fat than the group average. In case of intake of food with a significantly higher proportion of fat, it is necessary to reduce the number of serving units of fat in order to keep the total fat intake within the recommended value.

Adapted according to the "National guidelines for meals for children in primary schools" (2013).

Table 4. The calculation of daily needs of proteins, fats, carbohydrates and energy from milk and dairy products, regarding to the recommended serving units, considering the age

\begin{tabular}{|c|c|c|c|c|c|c|c|c|}
\hline \multirow{2}{*}{ Age group } & \multirow{2}{*}{ Servings } & \multicolumn{2}{|c|}{ Protein } & \multicolumn{2}{|c|}{ Fat } & \multicolumn{2}{|c|}{ Carbohydrates } & \multirow{2}{*}{$\begin{array}{l}\text { Energy } \\
\text { (Kcal) }\end{array}$} \\
\hline & & (g) & (Kcal) & (g) & (Kcal) & (g) & (Kcal) & \\
\hline $0-4$ month & 0 & 0 & 0 & 0 & 0 & 0 & 0 & 0 \\
\hline 4-12 month & 1 & 7 & 28 & $3(7)^{*}$ & $27(63)^{*}$ & 10 & 40 & $95(131)^{*}$ \\
\hline 1-4 year & 1 & 7 & 28 & 3 & $27(63)^{*}$ & 10 & 40 & 95 \\
\hline 4-7 year & 2 & 14 & 56 & $6(14)^{*}$ & $54(126)^{*}$ & 20 & 80 & $190(262)^{*}$ \\
\hline 7-10 year & 3 & 21 & 84 & $9(21)^{*}$ & $81(189)^{*}$ & 30 & 120 & $285(393)^{*}$ \\
\hline 10-13 year & 3 & 21 & 84 & 9 & $81(189)^{*}$ & 30 & 120 & 285 \\
\hline 13-15 year & 3 & 21 & 84 & 9 & $81(189)^{*}$ & 30 & 120 & 285 \\
\hline 15-19 year & 4 & 28 & 112 & $12(28)^{*}$ & $108(252)^{*}$ & 40 & 160 & $380(542)^{*}$ \\
\hline
\end{tabular}

*The figures in brackets refer to the food from certain groups of foods which contain a significantly higher proportion of fat than the group average. In case of intake of food with a significantly higher proportion of fat, it is necessary to reduce the number of serving units of fat in order to keep the total fat intake within the recommended value.

Adapted according to the "National guidelines for meals for children in primary schools" (2013).

Adapted according to the "Nutritional standards for the diet planning for children in kindergarten - menus and norms" (Vučemilović and Vujic Šisler, 2007).

Adapted according to the ESPGHAN Guidelines - European Association for Paediatric Gastroenterology, Hepatology and Nutrition (Agostoni et al., 2005). Adapted according to the Recommendations for Nutrition of Healthy Infants: Attitudes of the Croatian Society for Paediatric Gastroenterology, Hepatology and Nutrition (Kolaček et al., 2010).

Table 5. The values of one unit serving of milk and dairy products

\begin{tabular}{cccccccccc}
\hline Milk & $\begin{array}{c}\text { Acidophil/ } \\
\text { Yogurt }\end{array}$ & $\begin{array}{c}\text { Fresh } \\
\text { cheese }\end{array}$ & $\begin{array}{c}\text { Cream } \\
\text { cheese }\end{array}$ & $\begin{array}{c}\text { Sour cream } \\
12 \% \text { fat }\end{array}$ & Butter & Ice-cream & $\begin{array}{c}\text { Semi-hard } \\
\text { cheese }\end{array}$ & $\begin{array}{c}\text { Fruit } \\
\text { yogurt }\end{array}$ & Pudding \\
\hline $200 \mathrm{~g}$ & $180 \mathrm{~g}$ & $80 \mathrm{~g}$ & $35 \mathrm{~g}$ & $30 \mathrm{~g}$ & $6 \mathrm{~g}$ & $50 \mathrm{~g}$ & $20 \mathrm{~g}$ & $180 \mathrm{~g}$ & $125 \mathrm{~g}$ \\
\hline
\end{tabular}

Adapted according to the National Guidelines for the Nutrition of Students in Primary Schools (2013). 
age (from 7 up to 15 years); distribution of patients between regions regarding age is shown as well. Difference of the degree of disease between the regions was not significant $(\mathrm{P}=0.29)$, whereas in all the three regions was found the highest percentage (43.6\%) of acutely ill children (Table 6).

Comparisons of the distribution of patients between the regions due to the servings units are shown in table 7.

Comparing the distribution of patients between regions and according to the serving units, there were no significant differences $(\mathrm{P}=0.36)$. Since the serving units were defined according to age groups, it could be concluded that there were no significant differences in the patients' age. The highest number of tested patients ( $\mathrm{N}=50$ or $35.7 \%)$ showed an intake of 3 servings a day and were between 7 and 15 years old. The guidelines for healthy children recom- mend a minimum of 3 servings of milk and dairy products a day (Alebić, 2008), while the needs of an ill child are often higher. Thus, the observed data indicate that the serving units according to the age of a child should be increased for at least one serving unit, in order to reach the nutritional and energy needs of a child in the condition of disease and recovery.

\section{Meeting the Energy Needs}

A sufficient energy intake from food is required for the growth, metabolic and psychological function and for the muscle work. An extra energy intake is necessary for the growth of children or their recovery from illness (Ministry of Health, 2012). Table 8 shows the difference between the total actual energy intake and the recommended energy intake for three tested regions.

Table 6. The distribution of patients between regions: $\mathrm{X}^{2}$ test

\begin{tabular}{|c|c|c|c|c|c|c|c|c|c|}
\hline & \multicolumn{6}{|c|}{ Region } & & & \\
\hline & \multicolumn{2}{|c|}{ Central Croatia } & \multicolumn{2}{|c|}{$\begin{array}{l}\text { North Croatian } \\
\text { coast }\end{array}$} & \multicolumn{2}{|c|}{$\begin{array}{l}\text { East } \\
\text { Croatia }\end{array}$} & \multicolumn{3}{|c|}{ Total } \\
\hline & & $\mathrm{N}$ & $\%$ & $\mathrm{~N}$ & $\%$ & $\mathrm{~N}$ & $\%$ & $\mathrm{~N}$ & $\%$ \\
\hline Sex, N (\%), girls & & 51 & 53.7 & 12 & 41.4 & 12 & 75.0 & 75 & 53.6 \\
\hline \multirow{5}{*}{ Age } & 0 (0-4 month) & 6 & 6.3 & 4 & 13.8 & 1 & 6.3 & 11 & 7.8 \\
\hline & 1 (4 month-4 year) & 26 & 27.4 & 3 & 10.3 & 1 & 6.3 & 30 & 21.4 \\
\hline & 2 (4-7 year) & 16 & 16.8 & 4 & 13.8 & 4 & 25 & 24 & 17.1 \\
\hline & 3 (7-15 year) & 30 & 31.6 & 13 & 44.8 & 7 & 43.7 & 50 & 35.8 \\
\hline & 4 (15-19 year) & 17 & 17.9 & 5 & 17.2 & 3 & 18.7 & 25 & 17.9 \\
\hline \multirow{3}{*}{$\begin{array}{c}\text { The degree of } \\
\text { disease }\end{array}$} & Acutelly ill & 40 & 42.1 & 11 & 37.9 & 10 & 62.5 & 61 & 43.6 \\
\hline & Cronically ill & 38 & 40.0 & 14 & 48.3 & 6 & 37.5 & 58 & 41.4 \\
\hline & Oncology ill & 17 & 17.9 & 4 & 13.8 & 0 & 0 & 21 & 15.0 \\
\hline
\end{tabular}

Table 7. Comparison of the distribution of patients between the regions due to the serving units: $\mathrm{X}^{2}$ test

\begin{tabular}{|c|c|c|c|c|c|c|c|c|c|}
\hline & \multicolumn{6}{|c|}{ Region } & & & \\
\hline & \multicolumn{2}{|l|}{ Central Croatia } & \multicolumn{2}{|c|}{$\begin{array}{l}\text { North Croatian } \\
\text { coast }\end{array}$} & \multicolumn{2}{|c|}{ East Croatia } & \multicolumn{3}{|c|}{ Total } \\
\hline & & $\mathrm{N}$ & $\%$ & $\mathrm{~N}$ & $\%$ & $\mathrm{~N}$ & $\%$ & $\mathrm{~N}$ & $\%$ \\
\hline \multirow{5}{*}{$\begin{array}{l}\text { Serving units } \\
\text { (age of children) }\end{array}$} & 0 (0-4 month) & 6 & 6.3 & 4 & 13.8 & 1 & 6.3 & 11 & 7.9 \\
\hline & 1 (4 month-4 year) & 26 & 27.4 & 3 & 10.3 & 1 & 6.3 & 30 & 21.4 \\
\hline & 2 (4-7 year) & 16 & 16.8 & 4 & 13.8 & 4 & 25.0 & 24 & 17.1 \\
\hline & 3 (7-15 year) & 30 & 31.6 & 13 & 44.8 & 7 & 43.8 & 50 & 35.7 \\
\hline & 4 (15-19 year) & 17 & 17.9 & 5 & 17.2 & 3 & 18.8 & 25 & 17.9 \\
\hline
\end{tabular}


According to the results of this study, the difference between total energy intake and recommended energy intake between the tested regions (Table 8) was significant $(\mathrm{P}=0.039)$. The highest mean value of total energy intake was recorded in the northern Croatian coast $(1506.31 \mathrm{Kcal})$, i.e. the difference between the consumed and the recommended energy is the lowest $(3.8 \%)$, which indicates that the daily energy needs were met. While hospitalized children in central (1052.58 Kcal) and eastern Croatia ( $1498.93 \mathrm{Kcal}$ ) did not meet their daily energy needs - the children consumed $18.5 \%$ and $14.4 \%$, less than the recommended.
It is very important to achieve the recommended energy intake in hospitalized patients to prevent flare of the disease and to support faster recovery - chronic and oncology patients have increased energy and nutritional needs, 20-50 \% higher than recommended, depending on the age and gender (Bavdekar and al., 2002; Shaw and Lawson, 2008). So far, research concerning nutritional and energy intake in hospitalized paediatric patients have not been conducted.

Table 9 shows the difference between consumed and recommended energy intake from milk, in three tested regions.

Table 8. Difference between total acutal intake and recommended energy intake in three regions (KruskalWallis test)

\begin{tabular}{|c|c|c|c|c|c|c|c|c|}
\hline & \multirow{2}{*}{ Region } & \multirow{2}{*}{$\mathrm{N}$} & \multirow{2}{*}{$\begin{array}{l}\text { Energy* } \\
(\Delta \text { Kcal })\end{array}$} & \multirow{2}{*}{ Minimum } & \multirow{2}{*}{ Maximum } & \multicolumn{3}{|c|}{ Percentile } \\
\hline & & & & & & 25. & Median & 75. \\
\hline \multirow{3}{*}{$\begin{array}{l}\text { The difference } \\
\text { between total } \\
\text { actual energy intake } \\
\text { and recommended } \\
\text { energy intake: } \\
\text { total (\%) }\end{array}$} & $\begin{array}{l}\text { Central } \\
\text { Croatia }\end{array}$ & 95 & 1052.58 & $-100.0 \%$ & $90.1 \%$ & $-42.3 \%$ & $-18.5 \%$ & $0.2 \%$ \\
\hline & $\begin{array}{l}\text { North } \\
\text { Croatian } \\
\text { coast }\end{array}$ & 29 & 1506.31 & $-83.5 \%$ & $49.2 \%$ & $-19.6 \%$ & $3.8 \%$ & $17.0 \%$ \\
\hline & $\begin{array}{c}\text { East } \\
\text { Croatia }\end{array}$ & 16 & 1498.93 & $-100.0 \%$ & $121.4 \%$ & $-49.7 \%$ & $-14.4 \%$ & $39.2 \%$ \\
\hline & & & & \multicolumn{2}{|c|}{ Kruskal-Wallis } & $\mathrm{df}$ & \multicolumn{2}{|c|}{$\mathrm{P}$} \\
\hline \multicolumn{3}{|c|}{$\begin{array}{l}\text { The difference between total } \\
\text { actual energy intake and recom- } \\
\text { mended energy intake: total (\%) }\end{array}$} & & \multicolumn{2}{|c|}{6.509} & 2 & \multicolumn{2}{|c|}{0.039} \\
\hline
\end{tabular}

${ }^{*}$ The energy $(\mathrm{Kcal} \Delta)$ represents the average of total daily energy intake (Kcal) consumed from non-dairy food sources

Table 9. The difference between consumed energy from milk and dairy products compared to the recommended energy intake from milk and dairy products for three test regions (Kruskal-Wallis test)

\begin{tabular}{|c|c|c|c|c|c|c|c|c|}
\hline & \multirow{2}{*}{ Region } & \multirow{2}{*}{$\mathrm{N}$} & \multirow{2}{*}{$\begin{array}{l}\text { Energy* } \\
(\Delta \text { Kcal })\end{array}$} & \multirow{2}{*}{ Minimum } & \multirow{2}{*}{ Maximum } & \multicolumn{3}{|c|}{ Percentile } \\
\hline & & & & & & 25. & Median & 75. \\
\hline \multirow{4}{*}{$\begin{array}{l}\text { The difference } \\
\text { between consumed and } \\
\text { recommended } \\
\text { energy intake only from } \\
\text { milk (\%) }\end{array}$} & $\begin{array}{l}\text { Central } \\
\text { Croatia } \\
\end{array}$ & 89 & 253.42 & $-100.0 \%$ & $315.6 \%$ & $-40.7 \%$ & $34.4 \%$ & $68.1 \%$ \\
\hline & $\begin{array}{l}\text { North } \\
\text { Croatia } \\
\text { coast }\end{array}$ & 25 & 175.05 & $-100.0 \%$ & $67.7 \%$ & $-51.2 \%$ & $-20.1 \%$ & $5.4 \%$ \\
\hline & $\begin{array}{c}\text { East } \\
\text { Croatia }\end{array}$ & 15 & 248.46 & $-100.0 \%$ & $130.3 \%$ & $-53.8 \%$ & $-7.2 \%$ & $38.3 \%$ \\
\hline & & & & \multicolumn{2}{|c|}{ Kruskal-Wallis } & $\mathrm{df}$ & \multicolumn{2}{|c|}{$\mathrm{P}$} \\
\hline \multicolumn{4}{|c|}{$\begin{array}{l}\text { The difference between consumed } \\
\text { and recommended energy intake } \\
\text { only from milk (\%) }\end{array}$} & \multicolumn{2}{|c|}{7.741} & 2 & \multicolumn{2}{|c|}{0.021} \\
\hline
\end{tabular}

${ }^{*}$ Energy $($ Kcal $\Delta$ ) represents the average of total daily energy intake (Kcal) from milk and dairy products. 
The results in Table 9 show that the differences between the consumed and recommended energy from milk in three test regions were significant $(\mathrm{P}=0.021)$. The highest values were observed in central Croatia (253.42 Kcal or $34.4 \%$ ) which indicates a greater presence of milk meals in the daily menu, and thus the higher intake of daily energy needs from milk. The highest energy intake (Table 8) was observed in the northern Croatian coast, although this was due to non-dairy sources (Table 9).

Some studies carried out the importance of milk and dairy products in children diet, primarily with respect to their growth and development. Thus, for example, Wiley et al. (2011) found a positive correlation coefficient between the amount of milk and the tallness of children. Pre-school children who consumed more milk were higher than their peers with lowest milk consumption.

Milk and dairy products significantly contribute to the total energy intake in children. This study showed that more than $60 \%$ of the total number of children in central Croatia region consume up to 3 times more milk and dairy products than the recommended daily values.

\section{Meeting the needs for calcium and phosphorus}

Table 10 shows the ratio of the calcium intake from milk compared to the recommended calcium intake from all foods for three tested regions.

No significant differences $(\mathrm{P}=0.522)$ were found between the regions, and the results follow the results of the energy intake from dairy meals. The highest intake of calcium from milk was recorded in central Croatia (48.7\%), which is almost half of the total daily calcium intake from all foods, i.e. $400 \mathrm{mg}$, while the calcium intake from milk in eastern Croatia was $349.33 \mathrm{mg}(41 \%)$ or in the north Croatian coast $328.31 \mathrm{mg}(37.4 \%)$. This result speaks in favour of the statement that calcium from dairy products is highly available and makes more than $50 \%$ of the total calcium intake in children in European countries (Coudray, 2001). It also emphasises the importance of milk and dairy products in the diet of children considering their nutritional needs for calcium. Since the intake of calcium is important for children development, it is important to encourage the intake of this food group. Smith et al. (2011) investigated the impact of the glasses size which were used by the children (3-5 years old) to drink their milk. The obtained results showed that it was possible to influence the milk consumption. They found that that the size of the glass affected the amount of the consumed milk. If the milk would be served in larger cups or glasses, it could increase the intake of milk, and thus the calcium intake in children of a particular age group.

Table 11 shows the ratio of the phosphorus intake from milk compared to the recommended phosphorus intake from all foods for three tested regions.

The ratio of phosphorus intake from dietary sources compared to the recommended intake of phosphorus from all foods among the three regions (Table 11), the highest intake was observed in central Croatia (322.69 mg, $42.9 \%$ ), while the lowest intake in the northern Croatian coast $(241.56 \mathrm{mg}$, $26.4 \%)$. The differences found among the three regions were not significant $(\mathrm{P}=0.364)$. The $\mathrm{Ca} / \mathrm{P}$ ratio in milk is approximately 1.4:1 (Antunac and Havranek, 2013) which leads to conclusion that despite of the lower intake of phosphorus in relation to calcium in all regions, milk still represented the most commonly consumed food, while the dairy products rich in phosphorus (cheeses) were rarely consumed. The study by Murphy et al., (2008) confirmed that the dairy intake contributes to the intake of certain nutrients. They found that the consumption of regular or flavoured milk was related to the positive influence on the specific nutrient intake in children and adolescents. Murphy et al. (2008) also found that children and adolescents who included flavoured milk in their diets had a higher total intake of milk than children who consumed regular milk, and thus a higher intake of nutrients - vitamin A, calcium, phosphorus, magnesium and potassium. The results were significantly lower in children who did not consume any milk at all.

\section{The frequency of the consumption of milk and dairy products}

The results on the frequency of the milk and dairy products consumption carried out by frequency of milk and dairy products consumption questionnaire (FFQ - milk) showed that the intake of milk in hospitals was high in all tested regions, especially in the northern Croatian coast. From the results of the 
questionnaire on the consumption of dairy products outside the hospital a variety of dairy products which children consume in all the regions (Figure 1) could be noticed. Comparing Figures 1 and 2, a disproportion in the choice of foods from the milk and dairy group among the children outside of the hospital and during hospitalization could be observed. In hospitalized children there was a significantly greater consumption of butter, as well as higher intake of other dairy products (fresh, semi-hard and hard cheese, yogurt, acidophil and kefir, products without the addition of fruit, grains and similar), compared to the consumption of the same products in children outside the hospital. On contrary, during hospitalization the children consumed less milk desserts and ice-cream. It is interesting to note that in the northern Croatian coast the consumption of cocoa and chocolate milk, fresh cottage cheese and cream, cheese spreads and ice-cream was completely absent which could be explained by unadjusted menu to the child population why the children in this region had the lowest intake of milk and dairy products, i.e. had the lowest intake of energy, calcium and phosphorus originating from milk and dairy products. By increasing the intake of the above listed foods in the northern Croatian coast, the overall intake of dairy products in hospitalized children could be increased, as pointed by the study of De Pelsmaeker et al., (2013). These authors found out that the texture, taste and appearance were the main factors of the food choice among the children. The other two regions (northern and eastern Croatia) showed a variety of milk and dairy products offer, where the consumption in the hospital was in accordance with the one outside of the hospital. Furthermore, specialized centre for children diseases (Zagreb-northern

Table 10. The ratio of calcium intake from milk compared to the recommended calcium intake from all foods for three tested regions (Kruskal-Wallis test)

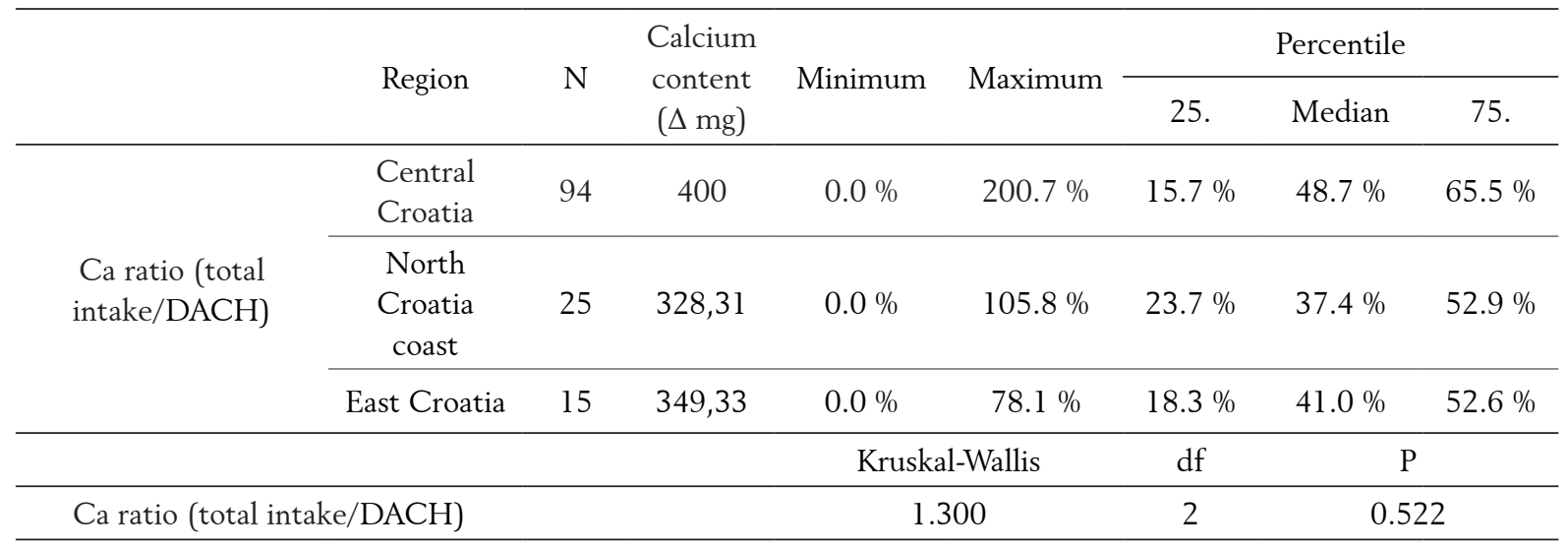

Table 11. The ratio of phosphorus intake from milk compared to the recommended phosphorus intake from all foods for three tested regions (Kruskal-Wallis test)

\begin{tabular}{|c|c|c|c|c|c|c|c|c|}
\hline & \multirow[b]{2}{*}{ Region } & \multirow[b]{2}{*}{$\mathrm{N}$} & \multirow{2}{*}{$\begin{array}{c}\text { Phosphorus } \\
\text { content } \\
(\Delta \mathrm{mg})\end{array}$} & \multirow[b]{2}{*}{ Minimum } & \multirow[b]{2}{*}{ Maximum } & \multicolumn{3}{|c|}{ Percentile } \\
\hline & & & & & & 25. & Median & 75. \\
\hline \multirow{4}{*}{$\begin{array}{c}\mathrm{P} \text { ratio (total } \\
\text { intake/DACH) }\end{array}$} & $\begin{array}{l}\text { Central } \\
\text { Croatia }\end{array}$ & 94 & 322.69 & $0.0 \%$ & $212.5 \%$ & $11.6 \%$ & $42.9 \%$ & $55.2 \%$ \\
\hline & $\begin{array}{c}\text { North } \\
\text { Croatia } \\
\text { coast }\end{array}$ & 25 & 241.56 & $0.0 \%$ & $93.0 \%$ & $19.5 \%$ & $26.4 \%$ & $41.6 \%$ \\
\hline & East Croatia & 15 & 321.89 & $0.0 \%$ & $86.5 \%$ & $14.4 \%$ & $34.8 \%$ & $61.8 \%$ \\
\hline & & & \multicolumn{3}{|c|}{ Kruskal-Wallis } & $\mathrm{df}$ & \multicolumn{2}{|c|}{$\mathrm{P}$} \\
\hline \multicolumn{3}{|c|}{$\mathrm{P}$ ratio (total intake/DACH) } & \multicolumn{3}{|c|}{2.024} & 2 & \multicolumn{2}{|c|}{0,364} \\
\hline
\end{tabular}


Croatia), shows the highest variety regarding milk and dairy products offer, which coincided with the consumption of milk and dairy products in children at home. Furthermore, results obtained by FFQmilk showed that the consumption of milk largely depended on the taste preferences. Children preferred milk with a certain taste, although they perceived it as less healthy than the milk without additions. Organoleptic attractiveness was the key factor in the choice of milk, unlike nutritional properties and importance for health. Moreover, 128 children $(58.98 \%)$ aged 6 to 13 stated that importance for health is their key motive in the choice of foods, but due to attractive taste they prefer the food options which are not recommended, i.e. which the subjects defined as "junk food".

\section{Conclusion}

Patients in the northern Croatian coast were the only group showing an adequate total energy intake, i.e. positive balance, while patients in the other two regions showed an insufficient energy intake. Patients in central Croatia had a significantly higher energy intake from milk and dairy products than in the other two regions, although, they were in default regarding the total energy intake. The ratios of the consumed calcium and phosphorus from dairy meals, considering the intake of total calcium and total phosphorus from all foods, were in accordance with the recommendations for the daily intake of dairy products, according to the age. In all regions hospitalized children met the recommended daily intake

Figure 1. Results of the questionnaire about frequency of consumption of milk and dairy products in the hospital for two days during the study
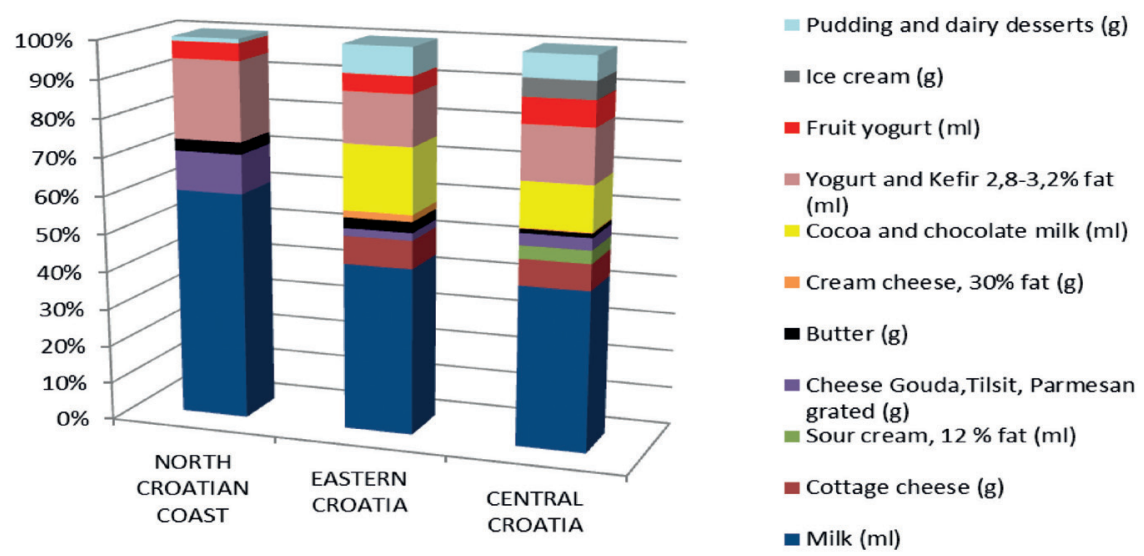

Figure 2. Results of the questionnaire about the frequency of consumption of milk and dairy products outside the hospital for a period of one month (eating habits of the examined children)
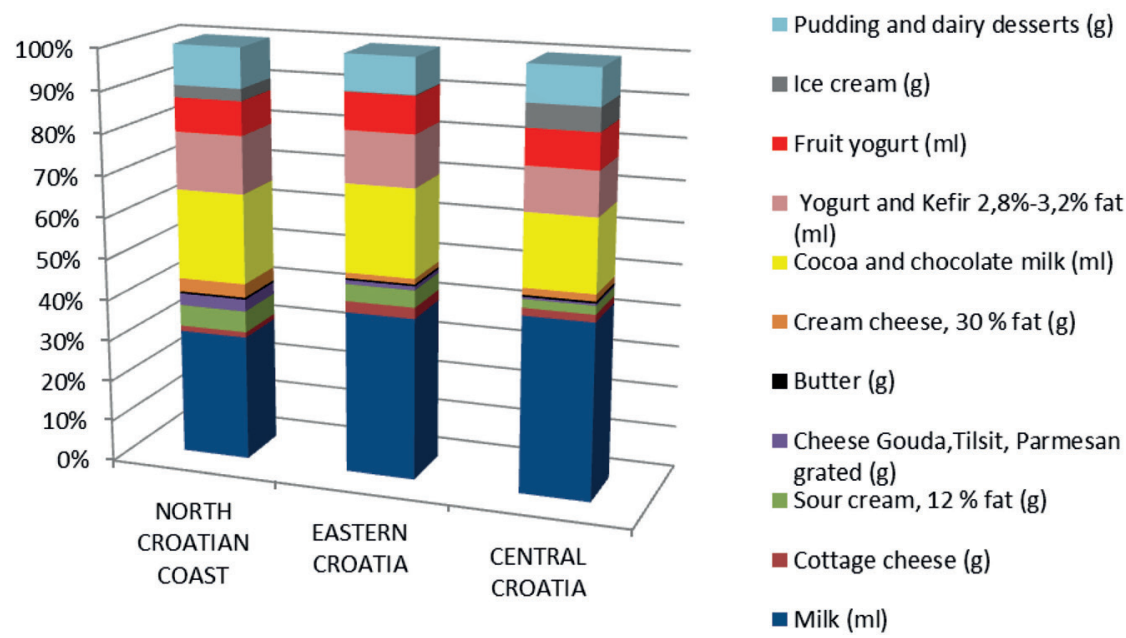
of calcium and phosphorus originating from milk and dairy products and the highest intake (48.7\% Ca and $42.9 \%$ P) was observed in central Croatia. According to the questionnaire on the frequency of the consumption of food and beverages, regular milk together with dairy desserts were the most common dairy foods consumed. The presence of various dairy products consumed in hospitals at the time of the study, concur with the general eating habits of children. In order to improve the intake of dairy meals in hospitalized children, further research is needed. Since the offer of different types of milk and dairy products in hospitals is limited, based on the results of the study we recommend an increase in the offer of dairy products in the daily hospital menu, especially fermented milk, enriched with fruit or other flavours, in order to achieve the optimal energy and nutrient daily intake (in particular calcium and phosphorus). Milk and dairy products greatly contribute to the quality of nutrition in hospitals, and their adequate consumption contributes significantly to the total energy intake and the intake of calcium and phosphorus.

\section{Mliječni obroci hospitalizirane djece kao izvor energije, kalcija $i$ fosfora $u$ zadovoljenju njihovih dnevnih potreba}

\section{Sažetak}

Mliječni obrok definira se kao točno određeno serviranje namirnice iz skupine mlijeka i mliječnih proizvoda. Zbog svoje nutritivne vrijednosti i složenog kemijskog sastava, mlijeko i mliječni proizvodi imaju važnu ulogu u prehrani djece. Bogat su izvor kalcija i fosfora te visokovrijednih bjelančevina, vitamina B skupine i mineralnih tvari. Zdrava djeca trebala bi konzumirati najmanje 3 serviranja mlijeka i mliječnih proizvoda dnevno što doprinosi ukupnom zadovoljenju energijskih i nutritivnih potreba, dok su potrebe oboljelog djeteta i veće ovisno o stanju organizma. Cilj ovog istraživanja bio je utvrditi zastupljenost mliječnih obroka u hospitalizirane djece i zadovoljenje energijskih potreba te potreba za kalcijem i fosforom kroz konzumaciju istih. Između unesene i preporučene energije iz mlijeka $u$ tri ispitivane regije utvrđene su značajne razlike $(\mathrm{P}=0,021)$. Najveće vrijednosti zabilježene su u Središnjoj Hrvatskoj
(253 Kcal ili 34,4 \%), a najmanje u Sjevernom hrvatskom primorju $(17,05$ Kcal ili 20,1\%), što ukazuje na veću zastupljenost mliječnog obroka u dnevnom jelovniku, a time i veće zadovoljenje potreba za energijom iz mlijeka. Nadalje, hospitalizirana djeca zadovoljavaju gotovo polovicu preporučenog dnevnog unosa kalcija i fosfora iz mliječnih obroka i to $\mathrm{u}$ svim regijama, a najviši postotak zadovoljenja je u Središnjoj Hrvatskoj, i to 48,7 \% ili 400 mg kalcija, odnosno 42,9 \% ili 322,69 mg fosfora, dok je preostali udio kalcija i fosfora porijeklom iz različitih bogatih nemliječnih prehrambenih izvora. Među regijama, najčešći konzumirani oblici mliječnih namirnica bili su konzumna mlijeka i mliječni deserti.

$$
\begin{aligned}
& \text { Ključne riječi: mliječni obrok, } \\
& \text { energijska vrijednost, kalcij, } \\
& \text { fosfor, mlijeko i mliječni } \\
& \text { proizvodi, hospitalizirana djeca }
\end{aligned}
$$

\section{Literature}

1. Agostoni, C., Axelson, I., Colomb, V., Goulet, O., Koletzko, B., Michaelsen, K.F., Puntis, J. W.L., Rigo, J., Shamir, R., Szajewska, H., Turck, D. (2005): The Need for Nutrition Support Teams in Pediatric Units: A Commentary by the ESPGHAN Committee on Nutrition, Journal of Pediatric Gastroenterology and Nutrition 41, 8-11. doi: 10.1097/01.MPG.0000163735.92142.87

2. Alebić, I.J. (2008): Prehrambene smjernice i osobitosti osnovnih skupina namirnica, Medicus 17 (1), 37-46.

3. Antunac, N., Havranek, J. (2013): Kemijski sastav mlijeka. In: Mlijeko-kemija, fizika, mikrobiologija (Eng. Milk-Chemistry, Physics and Microbiology), 3-120, Sveučilište u Zagrebu, Agronomski fakultet, Zagreb.

4. Bavdekar, A., Bhave, S., Pandit, A. (2002): Nutrition management in chronic liver disease, Indian Journal of Pediatrics 69, 427-31. doi: 10.1007/BF02722636

5. Campanozzi, A., Russo, M., Catucci, A., Rutigliano, I., Canestrino, G., Giardino, I., Romondia, A., Pettoello-Mantovani, M. (2009): Hospital-acquired malnutrition in children with mild clinical conditions, Nutrition 25 (5), 540-547. doi: 10.1016/j.nut.2008.11.026

6. Coudray, B. (2011): The contribution of dairy products to micronutrient intakes in France, The Journal of American College of Nutrition 30 (5), 410-414. doi: 10.1080/07315724.2011.10719984

7. De Pelsmaeker, S., Schouteten, J., Gellynck, X. (2013): The consumption of flavored milk among a children population. The influence of beliefs and the association of brands with emotions, Appetite 71, 279-286. doi: 10.1016/j.appet.2013.08.016 
8. De Souza Menezes, F., Leite, P.H., Nouguiera, P.C.K. (2011): Malnutrition as an independent predictor of clinicaloutcomein critically illchildren, Nutrition 28,267-270. doi: 10.1016/j.nut.2011.05.015

9. Department of Health (1991): Report on health and social subjects 41. Dietary Reference Values for Food Energy and Nutrients for the United Kingdom. Report of the Panel on Dietary Reference Values of the Committee on Medical Aspects of Food Policy, London.

10. DGE (Deutsche Gesellschaft für Ernährung) (2000): DACH-Referenzwerte für die Nährstoffzufuhr, 1. izd., Frankfurt am Main, Umschau/Braus.

11. European Commission (2010): Functional food, Brussels, Belgium.

12. Food and Agriculture Organization of the United States (FAO) and World Health Organization (WHO) (2001): Report of the Joint FAO/WHO Expert Consultation on Evaluation of Health and Nutritional Properties of Probiotics in Food Including Powder Milk with Live Lactic Acid Bacteria, Food and Agriculture Organization of the United Nations, Cordoba, Argentina.

13. Foods Standards Agency (2002): McCance and Widdowson's The Composition of Foods Sixth Summary Edition, Royal Society of Chemistry, Cambridge.

14. Goulet, O., Koletzko, B. (2004): Nutritional support in children and adolescents. In: Basics in Clinical Nutrition, (Sobotka, L.), 3. izd., Galén, Prague, 439-462.

15. Havranek, J., Tudor Kalit, M., Bažok, R., Đugum, J., Grbeša, D., Hadžiosmanović, M., Ivanković, A., Jakopović, I., Orešković, S., Rupić, V., Samaržija, D. (2014): Sigurnost hrane od polja do stola, M.E.P. d.o.o., Zagreb.

16. Joosten, K.F.M., Hulst, J.M. (2008): Prevalence of malnutrition in pediatric hospital patients, Journal of Pediatrics 20 (5), 590-596. doi: 10.1097/mop.0b013e32830c6ede

17. Joosten, K.F.M., Hulst, J.M. (2010): Malnutritionin pediatric hospital patients: Current issues, Nutrition 27, 133-137. doi: 10.1016/j.nut.2010.06.001

18. Kaić Rak, A., Antonić, K., Vest, K.E. (1990): Tablice o sastavu namirnica i pica. Zavod za zaštitu zdravlja RH.

19. Kolaček, S., Barbarić, I., Despot, R., Dujšin, M., Jelić, N., Hegeduš Jugvirth, M., Mišak, Z., Peršić, M., Pinotić, Lj., Radman, D., Senečić Čala, I., Tješić Drinković, D., Žaja, O. (2010): Preporuke za prehranu zdrave dojenčadi: stavovi Hrvatskog društva za dječju gastroenterologiju, hepatologiju i prehranu (DHPHP), Paediatria Croatica 54, 53-56.

20. Koletzko, B. (2004): Nutritional needs of children and adolescents. In: Basics in Clinical Nutrition (Sobotka L.), Prague, Galén, 3. izd., 45-55.

21. Koletzko, B., Cooper, P., Garza, C., Makrides, M., Uauy, R., Wang, W. (2008): Children's Nutrition - A practical reference guide, Karger, Basel.
22. Koletzko, B., von Kries, R., Closa Monasterolo, R., Escribano, J., Scaglioni, S., Giovannini, M., Beyer, J., Demmelmair, H., Gruszfeld, D., Dobrzanska, A., Sengier, A., Langhendries, J.P., Rolland Cachera, M.F., Grote, V; European Childhood Obesity Trial Study Group. (2009): Lower protein in infant formula is associated with lower weight up to age two years: a randomized clinical trial, American Journal of Clinical Nutrition 89 (6), 1836-1845. doi: 10.3945/ajcn.2008.27091

23. Mehta, N.M., Compher, C, A.S.P.E.N. Bord of directors (2009): A.S.P.E.N. Clinical Guidelines: Nutrition Support of the Critically Ill Child, Journal of Parenteral and Enteral Nutrition 33, 260. doi: 10.1177/0148607109333114

24. Miller, G.D., Jarvis, J.K., McBean, L.D. (2006): Handbook of Dairy Foods and $\mathrm{Nu}$ trition. $3^{\text {rd }}$ Ed., National Dairy Council. doi: 10.1201/9781420004311

25. Ministry of Health (2012): Food and Nutrition Guidelines for Healthy Children and Young People (Aged 2-18 years): A background paper - Revised February 2015, Wellington.

26. Močić Pavić, A., Detelić, D., Hojsak, I., Niseteo, T., Kolaček, S. (2015): Validation of a food frequency questionnaire for adolescents in Croatia, Journal of Pediatric Gastroenterology and Nutrition 60, 835-836.

27. Mouratidou, A., Vicente-Rodriguez, G., Gracia-Marco, L. Huybrechts, I., Sioen, I., Widhalm, K., Valtuena, J., Gonzales-Gross, M., Moreno, L. (2013): Associations of Dietary Calcium, Vitamin D, Milk Intakes, and 25-Hydroxyvitamin D with Bone Mass in Spanish Adolescents: the HELENA study. Journal of Clinical Densitometry 16 (1), 110-117. doi: 10.1016/j.jocd.2012.07.008

28. Murphy, M.M., Douglass, J.S., Johnson, R.K., Spence, L.A. (2008): Drinking flavored or plain milk is positively associated with nutrient intake and is not associated with adverse effects on weight status in US children and adolescents, Journal of the American Dietetic Association 108 (4), 631-639. doi: 10.1016/j.jada.2008.01.004

29. Nacionalne smjernice za prehranu učenika u osnovnim školama (2013): Ministarstvo zdravlja RH.

30. Norman, K., Pichard, C., Lochs, H., Pirlich, M. (2008): Prognostic impact of disease-related malnutrition, Clinical Nutrition 27, 5-15. doi: 10.1016/j.clnu.2007.10.007

31. Odluka o standardu prehrane bolesnika u bolnicama (2007): Narodne novine, broj 121, Zagreb.

32. Pawellek, I., Dokoupil, K., Koletzko, B. (2008): Prevalence of malnutrition in pediatric hospital patients, Clinical Nutrition 27, 72-76. doi: 10.1016/j.clnu.2007.11.001

33. Pravilnik o mlijeku i mliječnim proizvodima (2009): Narodne novine, broj 20, Zagreb. 
34. Vučemilović, Lj., Vujić Šisler, Lj. (2007): Prehrambeni standardi za planiranje prehrane djece u dječjem vrtiću-jelovnici i normativi. Gradski ured za obrazovanje, kulturu i šport-sektor predškolski odgoj. Zagreb.

35. Reicks, M., Degeneffe, D., Ghosh, K., Bruhn, C., Goodell, S., Gunther, C., Auld, G., Ballejos, M., Boushey, C., Cluskey, M., Misner, S., Olson, B., Wong, S., Zaghloul, S. (2011): Parent calcium-rich-food practices/ perceptions are associated with calcium intake among parents and their early adolescent children, Public Health Nutrition 1-10.

36. Rudolf, M.C., Logan, S. (2005): What is the long term outcome for children who fail to thrive? A systematic review, Archives of Disease in Childhood. 90, 925-931. doi: 10.1136/adc.2004.050179

37. Šatalić, Z., Alebić, I.J. (2008): Dijetetičke metode i planiranje prehrane, Medicus 17 (1), 27-36.

38. Shaw, V. (2014): Frontmatter. In: Clinical Paediatric Dietetics. 5. izd., John Wiley \& Sons, Ltd, Chichester.

39. Smith, S.R., Barnes, J.L., Knoll, S.E., Rhodes, K., Painter, J.E. (2011): Effect of Glass Size on Milk Consumption in Children 3 to 5 Years Old. Journal of the American Dietetic Association 11 (9), 106. doi: 10.1016/j.jada.2011.06.396
40. Tratnik, Lj., Božanić, R. (2012): Mlijeko i mliječni proizvodi. Hrvatska mljekarska udruga, Zagreb.

41. USDA (2015) USDA National Nutrient Database for Standard Reference, Release 28. Nutrient Data Laboratory. USDA - U.S. Department of Agriculture, Agricultural Research Service.

42. Watzl, B. (2013): Milk and dairy products - dietary recommendations and current intakes. Max Rubner-Institute. Karlsruhe, Germany.

43. Wiley, A. (2011): Cow Milk Consumption, Insulin-Like Growth Factor-I and Human Biology: A Life History Approach, American journal of human biology 1-9.

44. Yen, S.T, Lin, B. (2002): Beverage consumption among US children and adolescents: full-information and quasi maximum-likelihood estimation of a censored system, European Review of Agricultural Economics 24, 85-103. doi: 10.1093/erae/29.1.85

45. Yuan, W.L, Kakinami, L., Gray-Donald, K., Czernichow, S., Lambert, M., Paradis, G. (2013): Influence of Dairy Product Consumption on Children's Blood Pressure: Results from the QUALITY Cohort, Journal of the Academy of Nutrition and Dietetics 113, 936-941. doi: 10.1016/j.jand.2013.03.010 